\title{
Review \\ Genetic overlap between autism, schizophrenia and bipolar disorder
}

\author{
Liam S Carroll and Michael J Owen
}

\begin{abstract}
Address: MRC Centre for Neuropsychiatric Genetics and Genomics, Department of Psychological Medicine and Neurology, Cardiff University, Henry Wellcome Building, Heath Park, Cardiff CF14 4XN, UK.

Correspondence: Michael J Owen. Email: OwenMJ@cf.ac.uk
\end{abstract}

\begin{abstract}
There is strong evidence that genetic factors make substantial contributions to the etiology of autism, schizophrenia and bipolar disorders, with heritability estimates being at least $80 \%$ for each. These illnesses have complex inheritance, with multiple genetic and environmental factors influencing disease risk; however, in psychiatry, complex genetics is further compounded by phenotypic complexity. Autism, schizophrenia and bipolar disorder are effectively syndromic constellations of symptoms that define groups of patients with broadly similar outcomes and responses to treatment. As such the diagnostic categories are likely to be heterogeneous and the boundaries between them somewhat arbitrary. Recent applications of whole-genome technologies have discovered rare copy number variants and common singlenucleotide polymorphisms that are associated with risk of developing these disorders. Furthermore, these studies have shown an overlap between the genetic loci and even alleles that predispose to the different phenotypes. The findings have several implications. First, they show that copy number variations are likely to be important risk factors for autism and schizophrenia, whereas common single-nucleotide polymorphism alleles have a role in all disorders. Second, they imply that there are specific genetic loci and alleles that increase an individual's risk of developing any of these disorders. Finally, the findings suggest that some of the specific genetic loci implicated so far encode proteins, such as neurexins and neuroligins, that function in synaptic development and plasticity, and therefore may represent a common biological pathway for these disorders.
\end{abstract}

\section{Background}

It has long been recognized that psychiatric disorders and symptoms aggregate in families and the evidence for a substantial role for genetic factors is incontrovertible [1]. Genetic epidemiological studies of autism, bipolar disorder and schizophrenia show that the risk of developing one of these specific psychiatric illnesses is proportional to the amount of genetic material shared with an affected individual [1]. Heritability has been estimated as being at least $80 \%$ for all these disorders [2-4], which, to put it in context, is equivalent to that for type I diabetes (about 80\%) [5] but greater than that for breast cancer [6] or Parkinson's disease [7].
The majority of psychiatric disorders, like other common conditions, are genetically complex. In psychiatry, genetic complexity has been compounded by phenotypic complexity. Psychiatric diagnosis cannot be made on the basis of biological investigation or validated against a common pathogenesis. Psychiatric 'disorders' such as autism, schizophrenia and bipolar disorder are therefore effectively groups of symptoms making up syndromes that define groups of patients who show broadly similar outcomes and who respond similarly to treatment. Such diagnostic categories are therefore likely to be heterogeneous and the boundaries between them somewhat arbitrary.

Autism, schizophrenia and bipolar disorder have traditionally been considered as separate disease entities, although they do share some common behavioral characteristics and cognitive deficits. The distinction between schizophrenia and bipolar disorder has been justified for many years by reference to family studies showing that these disorders seem to 'breed true'. However, this view has been challenged [8], and a recent large-scale study has shown that relatives of individuals affected with schizophrenia have increased risks of bipolar disorder, and vice versa [9]. Definitive genetic epidemiological studies of the genetic relationship between autism and these disorders are lacking, although there is some evidence for shared genetic factors [10]. In recent years new molecular genetic findings, particularly from the application of genome-wide association studies (GWASs) and other genomic technologies [11-14], have implicated risk factors for these disorders, and this has allowed the possibility of a genetic relationship between them to be explored directly and current orthodoxies to be challenged [8-10].

\section{Copy number variant and rare allele studies}

Autism spectrum disorders (ASDs) such as autism, Asperger's syndrome and Rett's syndrome, are developmental psychiatric disorders with high heritability [15]. Over the past few years, genetic studies of ASDs have 
consistently identified rare and de novo point mutations and large structural variants present in genes encoding interacting synaptic proteins [16]. Such studies have reported co-segregation of putative high-risk alleles (such as deletions or point mutations) with ASDs or performed so-called 'burden analysis', in which different alleles of a particular gene are aggregated and the frequency in cases compared with that in controls. Initial studies of ASDs using small samples found rare missense point and structural mutations (such as copy number variants, CNVs) in the X-linked Neuroligin-3 and Neuroligin-4 (NLGN4) genes [17-19]. Neuroligins are a family of postsynaptic proteins that bind trans-synaptically to a family of pre-synaptic proteins called neurexins. Although these findings were interesting, incomplete penetrance of the mutations and lack of power made the results equivocal. However, missense mutations were subsequently identified in the Neurexin-1 (NRXN1) gene at a high frequency in individuals with autism [20]. These suggestive findings have been augmented by the results of recent genomic studies discussed below.

Traditional karyotyping, GWASs and comparative genome hybridization (CGH) analyses have been used to identify large chromosomal structural losses (deletions) and gains (duplications) in individuals with ASDs [21-24]. A burden analysis study of approximately 200 affected individuals identified two translocation events at $N R X N 1$ in separate samples, one disrupting the coding sequence and the other lying 5' to the gene [24]. A further study of over 1,000 pedigrees using approximately 10,000 single-nucleotide polymorphisms (SNPs) identified a $300 \mathrm{~kb}$ deletion of coding exons of NRXN1 co-segregating with autism [22].

Genome-wide analyses have also implicated further related and interacting synaptic protein-coding genes in the etiology of ASDs. First, a study of 427 ASD cases using approximately 500,000 SNPs identified a $6 \mathrm{Mb}$ de novo deletion encompassing NLGN4 [23] and a $270 \mathrm{~kb}$ deletion at $S H A N K 3$. SHANK3 encodes a post-synaptic protein that indirectly binds to neuroligins. Second, burden analyses revealed a high frequency of point mutations of SHANK3 in ASD cases $[25,26]$. Third, CNTNAP2, which encodes a member of the neurexin family that resides in the juxtaparanodal region of myelinated neurons [27], shows evidence for common-allele association with ASDs [28,29] as well as an increased burden of rare protein-coding mutations [30] and large de novo deletions [31,32].

The evidence implicating synaptic cell adhesion molecules and their related proteins in ASDs is strong. Data implicating them in schizophrenia is now arguably even stronger. A whole-genome screen for large chromosomal abnormalities using array-CGH performed in 93 individuals with schizophrenia identified a hemizygous loss at NRXN1 in one case [33]. The deletion of exon 1 was also present in an affected sibling and no deletions of NRXN1 were observed in 372 controls, suggesting that the allele may be pathogenic. The same study also found a large (1.4 Mb) de novo duplication event in an individual with an ASD that spanned $A P B A 2$; this is an intriguing result given that the gene encodes a protein (MINT2) that binds to intracellular domains of neurexins [33]. Further to this, an independent CGH study identified rare deletions of NRXN1 in monozygotic twins both diagnosed with early-onset schizophrenia [34].

Higher-density, lower-cost genome-wide screens using GWAS technologies have made it feasible to screen many thousands of individuals for smaller copy number variations. Using over 300,000 probes across the genome assayed in approximately 3,000 European cases and 10 times as many European controls, burden analysis revealed many deletions at the NRXN1 locus [35]. The authors [35] reported a significant excess of protein-coding deletions present in cases, a finding that is replicated in a similar analysis performed on an independent sample of approximately 3,000 cases of European descent and 3,000 controls [36] and also in two further studies using smaller sample sizes [37,38]. So far, no data implicating neuroligins and shanks in schizophrenia have been reported. However, hemizygosity of the CNTNAP2 gene, which encodes a member of the neurexin family, contactin-associated protein-like 2 (CASPR2), has been reported in schizophrenia [36,39] and also in individuals with mental retardation [39].

Although the available data provide relatively strong evidence that disruption of the Neurexin-1 locus (NRXN1) is a risk factor for schizophrenia [40] and ASDs [22,24], evidence in relation to bipolar disorder is lacking. This might reflect the relative paucity of studies addressing this hypothesis, but it could be the result of a discontinuity between bipolar disorder and schizophrenia in relation to the role of CNVs (see below).

The recent application of genome-wide technologies has shown that the burden of large, rare CNVs is increased in schizophrenia when compared with controls, and that this implicates specific loci $[34,36,41,42]$. Studies of such magnitude have not yet been performed for ASDs, although there is evidence for the involvement of specific CNVs [43]. In contrast, there is evidence that the global burden of duplications or deletions in bipolar disorder is substantially less than for schizophrenia and ASDs [44,45]. Specific deletions associated with schizophrenia include those at 22q11.2, 1q21.1 and 15q13.3, and these have also been found in association with mental retardation, autism and attention deficit hyperactivity disorder $[36,41,46-50]$ while that at $15 \mathrm{q} 13.3$ has also been implicated in idiopathic generalized epilepsy [51]. Therefore, just as for NRXN1 deletions, it is apparent that these large CNVs confer risk 
of a range of neurodevelopmental phenotypes, including autism, mental retardation and schizophrenia. However, similar evidence is lacking for bipolar disorder and there is a suggestion that CNVs might have a less prominent role in this phenotype.

\section{Genome-wide association studies}

The advent of the GWAS has allowed most of the common SNP variation in the human genome to be tested for association [52] and the first wave of such studies has been reported for schizophrenia [11,13,14,38,53], bipolar disorder [54-56] and autism [57]. Several loci have been implicated at genome-wide levels of statistical significance for schizophrenia [11,13,14,53], including ZNF804A (encoding a protein with zinc finger and nucleic acid binding domains) [11] and the major histocompatibility complex (MHC) region [13,14,53]. These studies have also provided strong evidence for genetic overlap between schizophrenia and bipolar disorder [13,58]. However, these associations implicate common alleles with small effects, and findings from GWASs do not yet clearly suggest a specific biological process. So far there have been no systematic comparisons of GWAS data for ASDs with those from schizophrenia or bipolar disorder. However, intriguing associations have been reported at voltage-gated calcium channel genes across all these phenotypes [56,58-60]. Furthermore, there have been recent reports of association for common alleles at several GABA receptor genes in a subtype of bipolar disorder and schizophrenia [61,62], which implicate loci also reported as associated with ASDs [23,63-65].

\section{A biological process disrupted across traditional diagnostic boundaries?}

The evidence for involvement of neurexins (NRXN1), neuroligins (NLGN4) and related proteins such as shanks (SHANK3), MINT2 (A2BP1) and CASPR2 (CNTNAP2) in ASDs is substantial and growing. There is also strong evidence implicating some of these genes in schizophrenia, although not all of them have been examined. Given this overlap, it is possible that the genes may be exerting their effects through a biological pathway common to both disorders.

The neurexins are a family of transmembrane proteins that have extracellular, membranous and intracellular domains $[16,66,67]$. Neurexins can be divided into two groups, $\alpha$ and $\beta$ neurexins; both are encoded by three genes. The neurexins are primarily expressed in neurons, where they are known as pre-synaptic heterophilic adhesion molecules, and they typically bind across the synapse to neuroligins. The neuroligins represent a similar class of proteins to neurexins and the binding of the two types of molecule to each other is controlled by alternative splicing. The intracellular domains of neurexins (and neuroligins) bind scaffolding proteins and assemble large molecular complexes that are known to link to synaptic systems such as receptors, ion channels and vesicle release machinery $[16,66,67]$.

Neurexins are best known for their ability to promote cell adhesion and synaptogenesis when neuroligins are present on the neighboring cell $[16,66,67]$. Even in non-neuronal cell lines, their expression promotes the generation of synapse-like machinery, such as vesicles. It seems that neurexins and neuroligins are necessary for both excitatory and inhibitory synaptogenesis, and possibly in functional synapse maturation. It has been hypothesized that neurexins and neuroligins are involved in the promiscuous generation of many synapses, before their activitydependent pruning $[16,66,67]$. However, multiple neurexin gene knockout studies in mice seem to contradict this and suggest that the neurexin-neuroligin complex is not essential for synapse formation but for synapse function. Deletions of a-Neurexin result in increased lethality, normal synapse number and gross anatomy but severely impaired synaptic functioning, a pattern strikingly similar to neuroligin gene knockouts $[16,66,67]$. Such biological roles fit with hypotheses of the etiology of autism and schizophrenia in which a neurodevelopmental insult and adult imbalance in excitatory and inhibitory neurotransmission occur in the absence of overt macro-pathology.

$S_{\text {SHANK3 }}$ is implicated in autism by several lines of evidence $[23,25,26,68-70]$ and functions as a post-synaptic scaffolding protein that binds indirectly to neuroligins, forming a potentially functional circuit of neurexinneuroligin-Shank that is dysregulated in ASDs. The involvement of $\alpha$-neurexins in pre-synaptic neurotransmission suggests a functional link with voltage-gated calcium channels [71,72], which are integral to presynaptic function and plasticity and have been implicated to be involved in autism, schizophrenia and bipolar disorder [56,58-60,73].

Therefore, the evidence from ASDs, schizophrenia and bipolar disorder suggests a convergence on specific processes involved in the development and regulation of synaptic transmission. Further work on the biology of neurexins, neuroligins and related proteins is certainly required and it seems likely that the pathogenic roles of these proteins will be illuminated by further human genetic studies.

\section{Conclusions}

Whole-genome studies of many thousands of affected individuals are uncovering evidence for genetic overlap between autism, schizophrenia and bipolar disorder. Studies of CNVs and other rare alleles have found overlap between autism and schizophrenia, whereas those of common SNP variants have shown overlap between schizophrenia and bipolar disorder. These findings suggest that schizophrenia, autism and other neurodevelopmental 
disorders may share underlying pathogenic mechanisms and challenges the view that these are completely unrelated diagnostic entities. The findings also support the view that schizophrenia has a stronger neurodevelopmental component than bipolar disorder and suggest that it lies on a gradient of decreasing neurodevelopmental impairment between syndromes such as mental retardation and autism, on one hand, and bipolar disorder on the other [74].

The identification of rare and common alleles predisposing to prototypically distinct psychiatric disorders provides challenges for the ways in which such disorders are diagnosed and researched. We have argued on the basis of recent genetic data that these findings point to common pathophysiological mechanisms, and this is now an important area for future research. We have based this conclusion on the fact that several rare CNVs, including deletions of $N R X N 1$, are associated with mental retardation, autism and schizophrenia, and on the overlap in common risk alleles seen between schizophrenia and bipolar disorder [11-13]. We do not propose that the disorders are the same phenomenologically, and we accept that there may be many genetic and environmental risk factors not shared between the phenotypes.

It is clear that much future work is required and equally clear that this should not be constrained by current categorical diagnostic systems. Such studies should explore the relationship of genes and other biological variables to dimensional measures of key domains of psychopathology across current diagnostic categories. We have previously argued the need to undertake such endeavors across the functional psychoses of schizophrenia and bipolar disorder [8]. However, recent data point to the need to consider a broader clinical spectrum that includes also autism and mental retardation/cognitive impairment [74].

\section{Competing interests}

The authors declare that they have no competing interests.

\section{Authors' contributions}

Both authors contributed equally to the preparation of this manuscript.

\section{References}

1. McGuffin P, Owen MJ, Gottesman II: Psychiatric Genetics \& Genomics. 1st edn. Oxford: Oxford University Press; 2002.

2. Freitag CM: The genetics of autistic disorders and its clinical relevance: a review of the literature. Mol Psychiatry 2007, 12:2-22.

3. McGuffin P, Rijsdijk F, Andrew M, Sham P, Katz R, Cardno A: The heritability of bipolar affective disorder and the genetic relationship to unipolar depression. Arch Gen Psychiatry 2003, 60:497-502.

4. Cardno AG, Gottesman II: Twin studies of schizophrenia: from bow-and-arrow concordances to star wars $\mathrm{Mx}$ and functional genomics. Am J Med Genet 2000, 97:12-17.

5. Hyttinen V, Kaprio J, Kinnunen L, Koskenvuo M, Tuomilehto J: Genetic liability of type 1 diabetes and the onset age among 22,650 young Finnish twin pairs: a nationwide follow-up study. Diabetes 2003, 52:1052-1055.

6. Locatelli I, Lichtenstein P, Yashin Al: The heritability of breast cancer: a Bayesian correlated frailty model applied to Swedish twins data. Twin Res 2004, 7:182-191.

7. Vaughan JR, Davis MB, Wood NW: Genetics of Parkinsonism: a review. Ann Hum Genet 2001, 65:111-126.

8. Craddock N, O'Donovan MC, Owen MJ: The genetics of schizophrenia and bipolar disorder: dissecting psychosis. J Med Genet 2005, 42:193-204.

9. Lichtenstein P, Yip BH, Bjork C, Pawitan Y, Cannon TD, Sullivan PF, Hultman CM: Common genetic determinants of schizophrenia and bipolar disorder in Swedish families: a population-based study. Lancet 2009, 373:234-239.

10. Rzhetsky A, Wajngurt D, Park N, Zheng T: Probing genetic overlap among complex human phenotypes. Proc Natl Acad Sci USA 2007, 104:11694-11699.

11. O'Donovan MC, Craddock N, Norton N, Williams H, Peirce T, Moskvina V, Nikolov I, Hamshere M, Carroll L, Georgieva L, Dwyer S, Holmans P, Marchini JL, Spencer CC, Howie B, Leung HT, Hartmann AM, Moller HJ, Morris DW, Shi Y, Feng G, Hoffmann P, Propping P, Vasilescu C, Maier W, Rietschel M, Zammit S, Schumacher J, Quinn EM, Schulze TG, et al: Identification of loci associated with schizophrenia by genome-wide association and follow-up. Nat Genet 2008, 40:1053-1055.

12. O'Donovan MC, Craddock NJ, Owen MJ: Genetics of psychosis; insights from views across the genome. Hum Genet 2009, 126:3-12.

13. Purcell SM, Wray NR, Stone JL, Visscher PM, O'Donovan MC Sullivan PF, Sklar P: Common polygenic variation contributes to risk of schizophrenia and bipolar disorder. Nature 2009, 460:748-752.

14. Stefansson $H$, Ophoff RA, Steinberg $S$, Andreassen $O A$, Cichon S, Rujescu D, Werge T, Pietilainen OP, Mors O, Mortensen PB, Sigurdsson E, Gustafsson O, Nyegaard M, Tuulio-Henriksson A, Ingason A, Hansen $T$, Suvisaari J, Lonnqvist J, Paunio T, Borglum AD, Hartmann A, Fink-Jensen $A$, Nordentoft M, Hougaard D, Norgaard-Pedersen B, Bottcher Y, Olesen J, Breuer R, Moller HJ, Giegling I, et al:: Common variants conferring risk of schizophrenia. Nature 2009, 460: 744-747.

15. Veenstra-Vanderweele J, Christian SL, Cook EH Jr: Autism as a paradigmatic complex genetic disorder. Annu Rev Genomics Hum Genet 2004, 5:379-405.

16. Sudhof TC: Neuroligins and neurexins link synaptic function to cognitive disease. Nature 2008, 455:903-911.

17. Jamain S, Quach $H$, Betancur $C$, Rastam $M$, Colineaux $C$, Gillberg IC, Soderstrom H, Giros B, Leboyer M, Gillberg C, Bourgeron $\mathrm{T}$ : Mutations of the $\mathrm{X}$-linked genes encoding neuroligins NLGN3 and NLGN4 are associated with autism. Nat Genet 2003, 34:27-29.

18. Laumonnier F, Bonnet-Brilhault F, Gomot M, Blanc R, David A, Moizard MP, Raynaud M, Ronce N, Lemonnier E, Calvas P, Laudier B, Chelly J, Fryns JP, Ropers HH, Hamel BC, Andres C, Barthelemy C, Moraine C, Briault S: X-linked mental retardation and autism are associated with a mutation in the NLGN4 gene, a member of the neuroligin family. Am J Hum Genet 2004, 74:552-557.

19. Yan J, Oliveira G, Coutinho A, Yang C, Feng J, Katz C, Sram J, Bockholt A, Jones IR, Craddock N, Cook EH Jr, Vicente A, Sommer SS: Analysis of the neuroligin 3 and 4 genes in autism and other neuropsychiatric patients. Mol Psychiatry 2005, 10:329-332.

20. Feng J, Schroer R, Yan J, Song W, Yang C, Bockholt A, Cook EH Jr, Skinner C, Schwartz CE, Sommer SS: High frequency of neurexin 1beta signal peptide structural variants in patients with autism. Neurosci Lett 2006, 409:10-13.

21. Sebat J, Lakshmi B, Malhotra D, Troge J, Lese-Martin C, Walsh T, Yamrom B, Yoon S, Krasnitz A, Kendall J, Leotta A, Pai D, Zhang R, Lee YH, Hicks J, Spence SJ, Lee AT, Puura K, Lehtimaki T, Ledbetter D, Gregersen PK, Bregman J, Sutcliffe JS, Jobanputra V, Chung W, Warburton D, King MC, Skuse D, 
Geschwind DH, Gilliam TC, et al.: Strong association of de novo copy number mutations with autism. Science 2007, 316:445-449.

22. Szatmari $P$, Paterson $A D$, Zwaigenbaum $L$, Roberts $W$, Brian $J$, Liu XQ, Vincent JB, Skaug JL, Thompson AP, Senman L, Feuk L, Qian C, Bryson SE, Jones MB, Marshall CR, Scherer SW, Vieland VJ, Bartlett C, Mangin LV, Goedken R, Segre A, Pericak-Vance MA, Cuccaro ML, Gilbert JR, Wright $\mathrm{HH}$, Abramson RK, Betancur C, Bourgeron T, Gillberg C, Leboyer $M$, et al.: Mapping autism risk loci using genetic linkage and chromosomal rearrangements. Nat Genet 2007, 39:319328.

23. Marshall CR, Noor A, Vincent JB, Lionel AC, Feuk L, Skaug J, Shago M, Moessner R, Pinto D, Ren Y, Thiruvahindrapduram B, Fiebig A, Schreiber S, Friedman J, Ketelaars CE, Vos YJ, Ficicioglu C, Kirkpatrick S, Nicolson R, Sloman L, Summers A, Gibbons CA, Teebi A, Chitayat D, Weksberg R, Thompson A, Vardy C, Crosbie V, Luscombe S, Baatjes R, et al.: Structural variation of chromosomes in autism spectrum disorder. Am J Hum Genet 2008, 82:477-488.

24. Kim HG, Kishikawa S, Higgins AW, Seong IS, Donovan DJ, Shen Y, Lally E, Weiss LA, Najm J, Kutsche K, Descartes M, Holt L, Braddock S, Troxell R, Kaplan L, Volkmar F, Klin A, Tsatsanis K, Harris DJ, Noens I, Pauls DL, Daly MJ, MacDonald ME, Morton CC, Quade BJ, Gusella JF: Disruption of neurexin 1 associated with autism spectrum disorder. $A m ~ J$ Hum Genet 2008, 82:199-207.

25. Durand CM, Betancur C, Boeckers TM, Bockmann J, Chaste P, Fauchereau F, Nygren G, Rastam M, Gillberg IC, Anckarsater H, Sponheim E, Goubran-Botros H, Delorme R, Chabane N, Mouren-Simeoni MC, de Mas P, Bieth E, Roge B, Heron D, Burglen L, Gillberg C, Leboyer M, Bourgeron T: Mutations in the gene encoding the synaptic scaffolding protein SHANK3 are associated with autism spectrum disorders. Nat Genet 2007, 39:25-27.

26. Moessner R, Marshall CR, Sutcliffe JS, Skaug J, Pinto D, Vincent J, Zwaigenbaum L, Fernandez B, Roberts W, Szatmari $\mathrm{P}$, Scherer SW: Contribution of SHANK3 mutations to autism spectrum disorder. Am J Hum Genet 2007, 81:12891297.

27. Burbach JP, van der Zwaag B: Contact in the genetics of autism and schizophrenia. Trends Neurosci 2009, 32:69-72.

28. Alarcon M, Abrahams BS, Stone JL, Duvall JA, Perederiy JV, Bomar JM, Sebat J, Wigler M, Martin CL, Ledbetter DH, Nelson SF, Cantor RM, Geschwind DH: Linkage, association, and gene-expression analyses identify CNTNAP2 as an autismsusceptibility gene. Am J Hum Genet 2008, 82:150-159.

29. Arking DE, Cutler DJ, Brune CW, Teslovich TM, West K, lkeda M, Rea A, Guy M, Lin S, Cook EH, Chakravarti A: A common genetic variant in the neurexin superfamily member CNTNAP2 increases familial risk of autism. Am J Hum Genet 2008, 82:160-164.

30. Bakkaloglu B, O'Roak BJ, Louvi A, Gupta AR, Abelson JF, Morgan TM, Chawarska K, Klin A, Ercan-Sencicek AG, Stillman AA, Tanriover G, Abrahams BS, Duvall JA, Robbins EM, Geschwind DH, Biederer T, Gunel M, Lifton RP, State MW: Molecular cytogenetic analysis and resequencing of contactin associated protein-like 2 in autism spectrum disorders. Am J Hum Genet 2008, 82:165-173.

31. Poot M, Beyer V, Schwaab I, Damatova N, Van't Slot R, Prothero J, Holder SE, Haaf T: Disruption of CNTNAP2 and additional structural genome changes in a boy with speech delay and autism spectrum disorder. Neurogenetics 2009. doi: 10.1007/s10048-009-0205-1.

32. Rossi E, Verri AP, Patricelli MG, Destefani V, Ricca I, Vetro A, Ciccone R, Giorda R, Toniolo D, Maraschio P, Zuffardi O: A $12 \mathrm{Mb}$ deletion at $7 \mathrm{q} 33-\mathrm{q} 35$ associated with autism spectrum disorders and primary amenorrhea. Eur J Med Genet 2008, 51:631-638.

33. Kirov G, Gumus D, Chen W, Norton N, Georgieva L, Sari M, O'Donovan MC, Erdogan F, Owen MJ, Ropers HH, Ullmann R: Comparative genome hybridization suggests a role for NRXN1 and APBA2 in schizophrenia. Hum Mol Genet 2008, $17: 458-465$.
34. Walsh T, McClellan JM, McCarthy SE Addington AM, Pierce SB, Cooper GM, Nord AS, Kusenda M, Malhotra D, Bhandar A, Stray SM, Rippey CF, Roccanova P, Makarov V, Lakshmi B, Findling RL, Sikich L, Stromberg T, Merriman B, Gogtay N, Butler P, Eckstrand K, Noory L, Gochman P, Long R, Chen Z, Davis S, Baker C, Eichler EE, Meltzer PS, et al.: Rare structural variants disrupt multiple genes in neurodevelopmental pathways in schizophrenia. Science 2008, 320:539-543.

35. Rujescu D, Ingason A, Cichon S, Pietilainen OP, Barnes MR, Toulopoulou T, Picchioni M, Vassos E, Ettinger U, Bramon E, Murray $R$, Ruggeri $M$, Tosato $S$, Bonetto $C$, Steinberg $S$, Sigurdsson E, Sigmundsson T, Petursson H, Gylfason A, Olason $\mathrm{Pl}$, Hardarsson $\mathrm{G}$, Jonsdottir GA, Gustafsson $\mathrm{O}$ Fossdal R, Giegling I, Moller HJ, Hartmann AM, Hoffmann P, Crombie C, Fraser G, et al:: Disruption of the neurexin 1 gene is associated with schizophrenia. Hum Mol Genet 2009, 18:988-996.

36. International Schizophrenia Consortium: Rare chromosomal deletions and duplications increase risk of schizophrenia. Nature 2008, 455:237-241.

37. Kirov G, Grozeva D, Norton N, Ivanov D, Mantripragada KK, Holmans P, Craddock N, Owen MJ, O'Donovan MC: Support for the involvement of large copy number variants in the pathogenesis of schizophrenia. Hum Mol Genet 2009, 18: 1497-1503.

38. Need AC, Ge D, Weale ME, Maia J, Feng S, Heinzen EL, Shianna KV, Yoon W, Kasperaviciute D, Gennarelli M, Strittmatter WJ, Bonvicini C, Rossi G, Jayathilake K, Cola PA, McEvoy JP, Keefe RS, Fisher EM, St Jean PL, Giegling I, Hartmann AM, Moller HJ, Ruppert A, Fraser G, Crombie C, Middleton LT, St Clair D, Roses AD, Muglia P, Francks C, et al: A genome-wide investigation of SNPs and CNVs in schizophrenia. PLoS Genet 2009, 5:e1000373.

39. Friedman JI, Vrijenhoek T, Markx S, Janssen IM, van der Vliet WA, Faas BH, Knoers NV, Cahn W, Kahn RS, Edelmann L, Davis KL, Silverman JM, Brunner HG, van Kessel AG, Wijmenga C, Ophoff RA, Veltman JA: CNTNAP2 gene dosage variation is associated with schizophrenia and epilepsy. Mol Psychiatry 2008, 13:261-266.

40. Kirov G, Rujescu D, Ingason A, Collier DA, O'Donovan MC, Owen MJ: Neurexin 1 (NRXN1) deletions in schizophrenia. Schizophr Bull 2009, 35:851-854.

41. Stefansson H, Rujescu D, Cichon S, Pietilainen OP, Ingason A, Steinberg S, Fossdal R, Sigurdsson E, Sigmundsson T, BuizerVoskamp JE, Hansen T, Jakobsen KD, Muglia P, Francks C, Matthews PM, Gylfason A, Halldorsson BV, Gudbjartsson D, Thorgeirsson TE, Sigurdsson A, Jonasdottir A, Jonasdottir A, Bjornsson A, Mattiasdottir $\mathrm{S}$, Blondal $\mathrm{T}$, Haraldsson $\mathrm{M}$, Magnusdottir BB, Giegling I, Moller HJ, Hartmann A, et al.: Large recurrent microdeletions associated with schizophrenia. Nature 2008, 455:232-236.

42. Xu B, Roos JL, Levy S, van Rensburg EJ, Gogos JA, Karayiorgou M: Strong association of de novo copy number mutations with sporadic schizophrenia. Nat Genet 2008, 40:880-885

43. Guilmatre A, Dubourg C, Mosca AL, Legallic S, Goldenberg A, Drouin-Garraud V, Layet V, Rosier A, Briault S, Bonnet-Brilhault F, Laumonnier F, Odent S, Le Vacon G, Joly-Helas G, David V, Bendavid C, Pinoit JM, Henry C, Impallomeni C, Germano E, Tortorella G, Di Rosa G, Barthelemy C, Andres C, Faivre L, Frebourg T, Saugier Veber $\mathrm{P}$, Campion D: Recurrent rearrangements in synaptic and neurodevelopmental genes and shared biologic pathways in schizophrenia, autism, and mental retardation. Arch Gen Psychiatry 2009, 66:947956.

44. Grozeva D, Kirov G, Ivanov D, Jones IR, Jones L, Green EK, St Clair D, Young AH, Ferrier IH, Farmer A, McGuffin $P$, Consortium WTCC, Holmans PA, Owen MJ, O'Donovan MC Craddock N: Rare copy number variants (CNVs): A point of rarity in genetic risk for bipolar disorder and schizophrenia? Arch Gen Psychiatry, in press.

45. Zhang D, Cheng L, Qian Y, Alliey-Rodriguez N, Kelsoe JR, Greenwood T, Nievergelt C, Barrett TB, McKinney R, Schork N, Smith EN, Bloss C, Nurnberger J, Edenberg HJ, Foroud T, 
Sheftner W, Lawson WB, Nwulia EA, Hipolito M, Coryell W, Rice J, Byerley W, McMahon F, Schulze TG, Berrettini W, Potash JB, Belmonte PL, Zandi PP, Mclnnis MG, Zollner S, et al.: Singleton deletions throughout the genome increase risk of bipolar disorder. Mol Psychiatry 2009, 14:376-380.

46. Ben-Shachar S, Lanpher B, German JR, Qasaymeh M, Potocki L, Nagamani SC, Franco LM, Malphrus A, Bottenfield GW, Spence JE, Amato S, Rousseau JA, Moghaddam B, Skinner C, Skinner SA, Bernes S, Armstrong N, Shinawi M, Stankiewicz P, Patel A, Cheung SW, Lupski JR, Beaudet AL, Sahoo T: Microdeletion 15q13.3: a locus with incomplete penetrance for autism, mental retardation, and psychiatric disorders. $J$ Med Genet 2009, 46:382-388.

47. Miller DT, Shen Y, Weiss LA, Korn J, Anselm I, Bridgemohan C, Cox GF, Dickinson H, Gentile J, Harris DJ, Hegde V, Hundley R, Khwaja O, Kothare S, Luedke C, Nasir R, Poduri A, Prasad K, Raffalli P, Reinhard A, Smith SE, Sobeih MM, Soul JS, Stoler J, Takeoka M, Tan WH, Thakuria J, Wolff R, Yusupov R, Gusella JF, et al.: Microdeletion/duplication at 15q13.2q13.3 among individuals with features of autism and other neuropsychiatric disorders. J Med Genet 2009, 46:242-248.

48. Pagnamenta AT, Wing K, Akha ES, Knight SJ, Bolte S, Schmotzer G, Duketis E, Poustka F, Klauck SM, Poustka A, Ragoussis J, Bailey AJ, Monaco AP: A 15q13.3 microdeletion segregating with autism. Eur J Hum Genet 2009, 17:687692 .

49. Sharp AJ, Mefford HC, Li K, Baker C, Skinner C, Stevenson RE, Schroer RJ, Novara F, De Gregori M, Ciccone R, Broomer A, Casuga I, Wang Y, Xiao C, Barbacioru C, Gimelli G, Bernardina BD, Torniero C, Giorda R, Regan R, Murday V, Mansour S, Fichera M, Castiglia L, Failla P, Ventura M, Jiang Z, Cooper GM, Knight SJ, Romano C, et al.: A recurrent 15q13.3 microdeletion syndrome associated with mental retardation and seizures. Nat Genet 2008, 40:322-328.

50. Mefford HC, Sharp AJ, Baker C, Itsara A, Jiang Z, Buysse K, Huang S, Maloney VK, Crolla JA, Baralle D, Collins A, Mercer C, Norga K, de Ravel T, Devriendt K, Bongers EM, de Leeuw N, Reardon W, Gimelli S, Bena F, Hennekam RC, Male A, Gaunt L, Clayton-Smith J, Simonic I, Park SM, Mehta SG, NikZainal S, Woods CG, Firth HV, et al:: Recurrent rearrangements of chromosome 1q21.1 and variable pediatric phenotypes. N Engl J Med 2008, 359:1685-1699.

51. Helbig I, Mefford HC, Sharp AJ, Guipponi M, Fichera M, Franke A, Muhle $\mathrm{H}$, de Kovel $\mathrm{C}$, Baker $\mathrm{C}$, von Spiczak $\mathrm{S}$, Kron KL, Steinich I, Kleefuss-Lie AA, Leu C, Gaus V, Schmitz B, Klein KM, Reif PS, Rosenow F, Weber Y, Lerche H, Zimprich F, Urak L, Fuchs K, Feucht M, Genton P, Thomas P, Visscher F, de Haan GJ, Moller RS, et al.: 15q13.3 microdeletions increase risk of idiopathic generalized epilepsy. Nat Genet 2009, 41: 160-162.

52. McCarthy MI, Hirschhorn JN: Genome-wide association studies: potential next steps on a genetic journey. Hum Mol Genet 2008, 17:R156-R165.

53. Shi J, Levinson DF, Duan J, Sanders AR, Zheng Y, Pe'er I, Dudbridge F, Holmans PA, Whittemore AS, Mowry BJ, Olincy A, Amin F, Cloninger CR, Silverman JM, Buccola NG, Byerley WF, Black DW, Crowe RR, Oksenberg JR, Mirel DB, Kendler $\mathrm{KS}$, Freedman R, Gejman PV: Common variants on chromosome 6p22.1 are associated with schizophrenia. Nature 2009, 460:753-757.

54. Genome-wide association study of 14,000 cases of seven common diseases and 3,000 shared controls. Nature 2007, 447:661-678.

55. Smith EN, Bloss CS, Badner JA, Barrett T, Belmonte PL, Berrettini W, Byerley W, Coryell W, Craig D, Edenberg HJ, Eskin E, Foroud T, Gershon E, Greenwood TA, Hipolito M, Koller DL, Lawson WB, Liu C, Lohoff F, Mclnnis MG, McMahon FJ, Mirel DB, Murray SS, Nievergelt C, Nurnberger J, Nwulia EA, Paschall J, Potash JB, Rice J, Schulze TG, et al:: Genome-wide association study of bipolar disorder in European American and African American individuals. Mol Psychiatry 2009, 14:755-763.

56. Sklar P, Smoller JW, Fan J, Ferreira MA, Perlis RH, Chambert K, Nimgaonkar VL, McQueen MB, Faraone SV, Kirby A, de
Bakker PI, Ogdie MN, Thase ME, Sachs GS, Todd-Brown K, Gabriel SB, Sougnez C, Gates C, Blumenstiel B, Defelice M, Ardlie KG, Franklin J, Muir WJ, McGhee KA, Maclntyre DJ, McLean A, VanBeck M, McQuillin A, Bass NJ, Robinson M, et al.: Whole-genome association study of bipolar disorder. Mol Psychiatry 2008, 13:558-569.

57. Wang K, Zhang H, Ma D, Bucan M, Glessner JT, Abrahams BS, Salyakina D, Imielinski M, Bradfield JP, Sleiman PM, Kim CE, Hou C, Frackelton E, Chiavacci R, Takahashi N, Sakurai T, Rappaport E, Lajonchere CM, Munson J, Estes A, Korvatska O, Piven J, Sonnenblick LI, Alvarez Retuerto Al, Herman EI, Dong $\mathrm{H}$, Hutman $\mathrm{T}$, Sigman $\mathrm{M}$, Ozonoff $\mathrm{S}$, Klin A, et al: Common genetic variants on 5 p14.1 associate with autism spectrum disorders. Nature 2009, 459:528-533.

58. Moskvina V, Craddock N, Holmans P, Nikolov I, Pahwa JS, Green E, Owen MJ, O'Donovan MC: Gene-wide analyses of genome-wide association data sets: evidence for multiple common risk alleles for schizophrenia and bipolar disorder and for overlap in genetic risk. Mol Psychiatry 2009, 14: 252-260.

59. Strom SP, Stone JL, Ten Bosch JR, Merriman B, Cantor RM, Geschwind DH, Nelson SF: High-density SNP association study of the $17 \mathrm{q} 21$ chromosomal region linked to autism identifies CACNA1G as a novel candidate gene. Mol Psychiatry 2009. doi: 10.1038/mp.2009.41.

60. Ferreira MA, O'Donovan MC, Meng YA, Jones IR, Ruderfer DM, Jones L, Fan J, Kirov G, Perlis RH, Green EK, Smoller JW, Grozeva D, Stone J, Nikolov I, Chambert K, Hamshere ML, Nimgaonkar VL, Moskvina V, Thase ME, Caesar S, Sachs GS, Franklin J, Gordon-Smith K, Ardlie KG, Gabriel SB, Fraser C Blumenstiel B, Defelice M, Breen G, Gill M, et al.: Collaborative genome-wide association analysis supports a role for ANK3 and CACNA1C in bipolar disorder. Nat Genet 2008, 40:1056-1058

61. Craddock N, O'Donovan MC, Owen MJ: Psychosis genetics: modeling the relationship between schizophrenia, bipolar disorder, and mixed (or "schizoaffective") psychoses. Schizophr Bull 2009, 35:482-490.

62. Hamshere ML, Green EK, Jones IR, Jones L, Moskvina V, Kirov G, Grozeva D, Nikolov I, Vukcevic D, Caesar S, GordonSmith K, Fraser C, Russell E, Breen G, St Clair D, Collier DA, Young AH, Ferrier IN, Farmer A, McGuffin P, Holmans PA, Owen MJ, O'Donovan MC, Craddock N: Genetic utility of broadly defined bipolar schizoaffective disorder as a diagnostic concept. Br J Psychiatry 2009, 195:23-29.

63. Kakinuma $H$, Ozaki $M$, Sato $H$, Takahashi $H$ : Variation in GABA-A subunit gene copy number in an autistic patient with mosaic $4 \mathrm{p}$ duplication (p12p16). Am J Med Genet $B$ Neuropsychiatr Genet 2008, 147B:973-975.

64. Bolton PF, Dennis NR, Browne CE, Thomas NS, Veltman MW, Thompson RJ, Jacobs $P$ : The phenotypic manifestations of interstitial duplications of proximal 15q with special reference to the autistic spectrum disorders. Am J Med Genet 2001, 105:675-685.

65. Cook EH Jr, Lindgren V, Leventhal BL, Courchesne R, Lincoln A, Shulman C, Lord C, Courchesne E: Autism or atypical autism in maternally but not paternally derived proximal 15q duplication. Am J Hum Genet 1997, 60:928-934.

66. Lise MF, El-Husseini A: The neuroligin and neurexin families: from structure to function at the synapse. Cell Mol Life Sci 2006, 63:1833-1849.

67. Dean C, Dresbach T: Neuroligins and neurexins: linking cell adhesion, synapse formation and cognitive function. Trends Neurosci 2006, 29:21-29.

68. Okamoto N, Kubota T, Nakamura Y, Murakami R, Nishikubo T, Tanaka I, Takahashi Y, Hayashi S, Imoto I, Inazawa J, Hosoka N, Kohsaka S, Uchino S: 22q13 Microduplication in two patients with common clinical manifestations: a recognizable syndrome? Am J Med Genet A 2007, 143A:2804-2809.

69. Wilson HL, Wong AC, Shaw SR, Tse WY, Stapleton GA, Phelan $\mathrm{MC}$, Hu S, Marshall J, McDermid HE: Molecular characterisation of the 22q13 deletion syndrome supports the role of haploinsufficiency of SHANK3/PROSAP2 in the major neurological symptoms. J Med Genet 2003, 40:575-584. 
70. Sykes NH, Toma C, Wilson N, Volpi EV, Sousa I, Pagnamenta AT, Tancredi R, Battaglia A, Maestrini E, Bailey AJ, Monaco AP: Copy number variation and association analysis of SHANK3 as a candidate gene for autism in the IMGSAC collection. Eur J Hum Genet 2009, 17:1347-1353.

71. Dudanova I, Sedej S, Ahmad M, Masius H, Sargsyan V, Zhang W, Riedel D, Angenstein F, Schild D, Rupnik M, Missler M: Important contribution of alpha-neurexins to $\mathrm{Ca2+-}$ triggered exocytosis of secretory granules. J Neurosci 2006, 26:10599-10613.

72. Catterall WA, Few AP: Calcium channel regulation and presynaptic plasticity. Neuron $2008,59: 882-901$.

73. Green EK, Grozeva D, Jones I, Jones L, Kirov G, Caesar S, Gordon-Smith K, Fraser C, Forty L, Russell E, Hamshere ML,
Moskvina V, Nikolov I, Farmer A, McGuffin P, Holmans PA, Owen MJ, O'Donovan MC, Craddock N: The bipolar disorder risk allele at CACNA1C also confers risk of recurrent major depression and of schizophrenia. Mol Psychiatry 2009. doi: 10.1038/mp.2009.49.

74. Craddock N, Owen MJ: The Kraepelinian dichotomy: Going, going, ... but still not gone. Br J Psychiatry, in press.

Published: 30 October 2009

doi:10.1186/gm102

(C) 2009 BioMed Central Ltd 